\title{
HOUSING QUALITY ASSESSMENT CRITERIA
}

Scientiffic paper / Znanstveni rad

\author{
Ivana Brkanić \\ Josip Juraj Strossmayer University of Osijek, Faculty of Civil Engineering Osijek, mag.ing.arch \\ Corresponding author: ibrkanic@gfos.hr
}

\begin{abstract}
An apartment is a basic need and a primary unit of human habitation, and in most cases, it represents the largest investment of someone's life. For that reason, and because of constant changes in housing needs, it is necessary to continuously evaluate the housing quality of apartments. The aim of this paper is to provide an overview of the criteria used for housing quality assessments in existing studies. Due to the large number of defined criteria, four groups of criteria were established: apartment unit quality criteria, apartment building quality criteria, neighborhood quality criteria, and social and economic criteria. The defined criteria can be divided according to the different scales of the assessed spaces (apartment unit, building, and neighborhood), and according to the method of assessment (quantitative or qualitative). The trend suggests that the numbers of individual criteria and criteria groups have increased over time, and they have become more complex. Also, it can be concluded that the number of criteria related to adaptability and sustainability will increase and lead to even more complex criteria relations. The defined criteria can be used in future research and serve as a basis for the proposal of a set of highly valuable criteria for examining attitudes toward housing quality.
\end{abstract}

Keywords: housing quality; apartment unit; residential building; evaluation criteria

\section{KRITERIJI ZA OCJENU KVALITETE STANA}

Sažetak: Stan kao primarno mjesto čovjekova obitavanja predstavlja jednu od osnovnih ljudskih potreba. U većini slučajeva on predstavlja i najveću investiciju u nečijem životu. Upravo je zbog navedenih razloga, ali i konstantnih promjena u stambenim potrebama, potrebno kontinuirano provoditi ispitivanja kvalitete stanovanja. Svrha ovoga rada je na temelju dosad provedenih i dostupnih istraživanja utvrditi kriterije za ocjenu kvalitete stanovanja u višestambenim zgradama. Zbog velikog broja definiranih kriterija, izvršena je njihova podjela na četiri grupe: kriteriji za ocjenu kvalitete stambene jedinice, kriteriji za ocjenu kvalitete stambene zgrade, kriteriji za ocjenu kvalitete susjedstva te socijalni i ekonomski kriteriji za ocjenu kvalitete stanovanja. Definirani kriteriji se mogu podijeliti prema mjerilu prostora koji je ocjenjivan (na kriterije koji se odnose na stan, zgradu i susjedstvo) te na kriterije koji se odnose na metodu ocjenjivanja (na kvantitativne i kvalitativne kriterije). Trend ukazuje kako broj pojedinačnih kriterija i grupa kriterija raste te kako oni postaju sve složeniji. Također, pretpostavlja se kako će broj kriterija koji se odnose na adaptabilnost i održivost rasti te kako će odnosi između kriterija postati još složeniji. Definirani kriteriji mogu se koristiti u daljnjim istraživanjima te mogu poslužiti kao podloga za izradu najvažnijih kriterija za ispitivanje stavova o kvaliteti stanovanja.

Ključne riječi: kvaliteta stanovanja; stan; višestambena zgrada; kriteriji za ocjenjivanje 


\section{INTRODUCTION}

An apartment is one of the most basic human needs [1]. It is the first unit of a society and the primary unit of human habitation [2]. For most people, an apartment represents the largest investment of their life [3]. In general, housing is one of the major components of the social and economic development of a society [4], and a result of multiple social, economic, and physical processes that involve issues of location, construction quality, cost, long-term financing, and household preferences [5].

In recent decades, modern lifestyles and housing needs have dramatically changed as a result of various social factors: changes in perceptions of the traditional family and the degree of independence within a family, the replacement of private living spaces with various other amenities, the conversion of living spaces in the pursuit of multi-functionality, increased mobility, and new information technologies that affected globalization and overall individualization [6]. Changes in housing needs have made necessary the constant assessment of housing quality so that it always meets the needs of its users.

For the sake of further research on housing quality, this paper will provide an overview of the criteria used to assess housing quality in domestic and foreign research. The main objective of this study is to identify specific criteria that are relevant to the assessment of housing quality.

\section{HOUSING QUALITY AND USER SATISFACTION}

A housing quality assessment provides necessary information on the current state of the housing stock, important information as an input for future projects, and insight into the current wishes and needs of its users. Most of the analyzed research on housing quality was based on user satisfaction.

Housing quality is a broad term that encompasses many aspects and has both an objective and a subjective dimension. The objective dimension consists of many aspects of particular significance; examples include dwelling type, number of rooms, presence of facilities, and the condition of the dwelling [7]. The subjective dimension includes user characteristics that lead to specific needs, desires, and expectations. In short, housing quality criteria include housing conditions such as the characteristics or properties of a physical environment and the characteristics of its users [8].

According to Streimikiene [8], housing satisfaction may be defined as the "perceived gap between a respondent's needs and aspirations and the reality of the current residential context." Housing satisfaction is also defined as the experience of pleasure or gratification derived from living in a specific place [9].

Housing satisfaction is considered to be a useful criterion for assessing housing quality because it indicates the level of success, measures the users' affective and cognitive responses, highlights the unattractive aspects of the housing environment, and anticipates user responses to future conditions. It also helps to identify the contribution of different factors to satisfaction, differences between various types of factor, and the relationship between different dimensions of housing [10]. User satisfaction is the most important measure of housing quality [11]: the higher the quality of the apartment the higher the expected satisfaction of its user. Recent domestic and foreign research on the topic of housing quality and housing quality assessment criteria will be presented in the following section.

\section{LITERATURE REVIEW}

Research on the subject of housing quality has been conducted since the mid-20th century. The oldest available research dates from the mid-1940s and was conducted in residential areas in the United States. In 1946, Solow [12] measured the value of housing quality using a survey that comprised two distinct parts. The first covered the appraisal of structures and apartments, and the second the evaluation of environmental factors [12]. Two years later, Twichell developed a method for measuring housing quality. It introduced an overcrowding factor into housing quality assessment and was focused on assessing the physical neighborhood environment [13]. In 1970, Kain and Quigley estimated the market value of specific housing aspects. They measured the qualitative and quantitative dimensions of housing quality on several levels: apartment units, structure, parcels, and micro-neighborhoods [14].

Brkanić, I 
To this day, quality assessment research has remained in a similar framework, but the number of evaluated indicators has increased. Housing quality is evaluated from the perspective of various experts [15-18], users [9, 1922], and apartment buyers [23-26]. Housing quality assessments are carried out in order to maximize design quality, ensure the healthy housing quality of apartments, assess apartment safety, ensure high indoor thermal and acoustic comfort, determine which spatial quality factors are affected by renovations, and so on.

\subsection{Foreign housing quality research}

Due to the large number of foreign studies on housing quality, this research narrowed its focus mostly to the ones conducted over the last 10 years. Existing research can be divided into two categories: research dealing with tenant satisfaction with the conditions in the apartment (health conditions [18, 27-29], security [23, 29], indoor thermal and acoustic comfort [30], and atmosphere and comfort [30, 31]) and research that measures total satisfaction with housing through the assessment of apartments, buildings, and immediate surroundings [8, 9, 15, 17, 23, 32, 33].

The conclusions of these studies were made on the basis of conducted tenant surveys. The surveys measured customer satisfaction using a number of criteria relevant to the assessment of specific housing characteristics. As a special category, research dealing with the definition of housing characteristics essential to future tenants (apartment buyers) should be singled out [23-26].

The studies mentioned in this paragraph should be highlighted due to the researched aspects of apartment quality and the manner in which the surveys were conducted. In 2015, Mridha measured the overall residential satisfaction of dwellers living in developer-built medium-rise apartment buildings [9]. Sima made a comparative study of respondents' impressions of and preferences for different apartment layouts [26] in order to optimize the floor plan design of medium-sized apartments. Choi and Cho conducted occupant and customer satisfaction expert evaluations of pre-classified apartment components [17]. In 2016, Lea and associates investigated social housing in order to meet the welfare needs of regular citizens by comparing quality and cost across apartments [32]. James measured the long-term impact of structural features and physical amenities on the residential satisfaction of renters in multifamily housing [19]. In 2016 in New Zealand, Bennett et al. conducted a field test of a rental housing warrant of fitness to assess its practicality and utility for improving housing quality in terms of health and safety [29]. In China, Shin et al. investigated changes in public perception of an apartment through an analysis of apartment characteristics that appeared on television and in newspaper advertisements [34].

Kang et al. developed the Health Performance Indicator, which was utilized for the comparison and analysis of public housing characteristics that were evaluated by experts and residents [18]. Cho and Kang conducted similar research that focused on residents' quality of life [28].

In 2011, Haddad and associates investigated the main factors that influence customers' purchase behavior toward apartments and tried to identify the factors that most influence buying [23]. In Ljubljana, Slovenia, Nahtigal and Grum conducted market research with the intention of creating a so-called value frame of influential factors related to a particular type of potential buyer [24].

In any review of foreign research, in the spirit of technology advancement it is necessary to mention online tools for housing quality assessment. Housing Quality Indicators (HQI), designed in the United Kingdom from 2008 to 2015 , is an online toolkit for the measurement, evaluation, and improvement of buildings' design quality [35]. It was designed for evaluation of housing schemes on the basis of quality rather than just cost. It contains 10 indicators that measure housing quality and presents a series of questions on location, site, unit, and external environment quality. The Building for Life criteria were designed parallel to the HQI; they represent a national standard for well-designed homes and neighborhoods. The 20 criteria measure the functionality, attractiveness, and sustainability of housing, and cover the following housing aspects: the environment and community, character, streets, parking and pedestrianization, design, and construction [36]. The Système d'évaluation de logements or Housing Assessment System is a Swiss online tool developed to provide assistance in the design, evaluation, and comparison of residential objects [37]. It consists of 25 criteria and measures the quality of a building in three aspects: situation, immediate environment, and housing [37]. 


\subsection{Housing quality research in Croatia}

There are a small number of Croatian studies that measure housing quality or explore housing quality criteria. Although the focus of this paper is on recent ones, it is necessary to mention a few important studies conducted before 2000. The Construction Institute of Zagreb's Department of Construction developed a model of apartment evaluation that was used to measure the quality of apartments and apartment buildings built under a social housing construction scheme between 1976 and 1984. The model had 10 groups of quality indicators, including the following: apartment layout and size, the position of the apartment in the building, common areas in the building, and different types of utility [38]. In 1978, Čaldarović and Richter conducted a study that presented findings on housing issues and the relationships between residential users and their indirect and wider residential area [39]. It is important to mention Goran Poljanec's dissertation, entitled "The dwelling's desirable properties" [38]. In the dissertation, based on a review of the literature and research conducted before 1990, the author studied housing characteristics and determined a list of desirable apartment, building, and settlement properties.

Homadovski and Rogić examined, through an architectural evaluation survey, users' attitudes toward the quality of different physical characteristics of apartments, apartment buildings, and building surroundings [19]. In 2005 , Bezek and associates developed a model for evaluating occupiable space in residential buildings. The model was based on elements of multi-criteria analyses and the subject was evaluated using a greater number of criteria, which had different shares in the final rating [16]. The previously mentioned research served as a starting point for two dissertations. Vezilić Strmo created a model for sustainability evaluation of existing residential buildings. The model is based on apartment buildings in Zagreb built between 1945 and 1970 and measures the spatial sustainability, adaptability, and functional organization of apartments [40]. In 2015, Luka Korlaet [41] developed a model for the architectural evaluation of apartments according to the following criteria: orientation, quality of the spatial organization, the usability of construction, installation nodes, and energy rationality. The model was tested on apartments built within the framework of a social housing program.

\section{HOUSING QUALITY ASSESSMENT CRITERIA}

Based on an analysis of the existing research, 25 studies were singled out and used to identify specific housing quality criteria. Because there were so many, the housing quality assessment criteria were divided into four main categories: apartment unit quality assessment criteria; apartment building assessment criteria; neighborhood quality assessment criteria, and social and economic criteria. 
Table 1 Apartment unit quality assessment criteria ${ }^{1}$

\begin{tabular}{|c|c|c|c|c|c|c|c|c|c|c|c|c|c|c|c|c|c|c|c|c|c|c|c|c|}
\hline \multicolumn{3}{|r|}{ APARTMENT UNIT quality criteria } & 19 & 16 & 8 & \begin{tabular}{l|l|}
20 & 34 \\
\end{tabular} & 22 & 17 & 9 & \begin{tabular}{l|l}
30 & 2 \\
\end{tabular} & $24 \sqrt{2}$ & 25 & 23 & 213 & \begin{tabular}{l|l}
32 & 1 \\
\end{tabular} & $15 \mid 2$ & 26 & 31 & \begin{tabular}{|l|l|}
18 & 33 \\
\end{tabular} & 35 & 36 & \begin{tabular}{l|l}
37 & 4 \\
\end{tabular} & $\begin{array}{lll}0 & 41 \\
\end{array}$ & \\
\hline \multirow{4}{*}{\multicolumn{2}{|c|}{$\begin{array}{l}\overline{\frac{\pi}{0}} \\
\bar{\Phi} \\
\bar{\Phi} \\
. \subseteq\end{array}$}} & apartment area & & & & & & & & & $x$ & & $x$ & & & & & & & $x$ & & & $x$ & \\
\hline & & position in building - floor & $x$ & $x$ & & & & & & & & $\mathrm{x}$ & & & & & & & & & & s & $x$ & \\
\hline & & unit plan and size - layout & $\mathrm{x}$ & $x$ & & $\mathrm{x}$ & & & $x$ & & & $\mathrm{x}$ & & $\mathrm{x}$ & $x$ & $x$ & & & $x$ & $x$ & & $x$ & $\mathrm{x}$ & \\
\hline & & $\begin{array}{l}\text { condition and design of walls, floors, } \\
\text { windows, doors }\end{array}$ & $\mathrm{x}$ & & $x$ & & & & $\mathrm{x}$ & & $\mathrm{x}$ & $x$ & & $\mathrm{x}$ & & $x$ & $\mathrm{x}$ & & & & & & $x$ & \\
\hline \multirow{5}{*}{\multicolumn{2}{|c|}{$\sum_{0}^{0}$}} & $\begin{array}{l}\text { interior of living room, kitchen, bedroom, } \\
\text { and bathroom }\end{array}$ & $\mathrm{x}$ & $x$ & & $\mathrm{x}$ & $\mathrm{x}$ & $\mathrm{x}$ & & & & $\mathrm{x}$ & & & $x$ & $\mathrm{x}$ & $x$ & $\mathrm{x}$ & $x$ & $x$ & & $\mathrm{x}$ & \begin{tabular}{l|l}
$x$ & $x$
\end{tabular} & \\
\hline & & $\begin{array}{l}\text { living room, kitchen, bedroom, and } \\
\text { bathroom size, location, number, and } \\
\text { orientation }\end{array}$ & $\mathrm{x}$ & $x$ & $\mathrm{x}$ & & & & $x$ & & & & & $\mathrm{x}$ & $\mathrm{x}$ & $\mathrm{x}$ & $x$ & $\mathrm{x}$ & $\mathrm{x}$ & $x|x|$ & & $\mathrm{x}$ & \begin{tabular}{l|l}
$x$ & $x$
\end{tabular} & \\
\hline & & entrance and hallway & $\mathrm{x}$ & & & & & $x$ & & & & & & & & & & & & $x$ & & & & \\
\hline & & storage & $x$ & & & & & & & & & & & $x$ & & & & & & $x$ & & $x$ & & \\
\hline & & $\begin{array}{l}\text { outer spaces - balcony, terrace, garden } \\
\text { (existence, size, position) }\end{array}$ & $\mathrm{x}$ & $x$ & & $\mathrm{x}$ & & $\mathrm{x}$ & $x$ & & & $\mathrm{x}$ & $x$ & & & $x \mid x$ & $x$ & & & $x|x|$ & & & \begin{tabular}{l|l}
$x$ & $x$
\end{tabular} & \\
\hline \multirow{5}{*}{\multicolumn{2}{|c|}{ 응 }} & $\begin{array}{l}\text { well-being and environment-friendly design } \\
\text { and materials }\end{array}$ & & & & $x$ & & & $x$ & & $x$ & & & & & $x$ & & & & $x$ & $\mathrm{x}$ & & & \\
\hline & & high-tech solutions & & & & $\mathrm{x}$ & & & & & & & & & & & & & & & & & & \\
\hline & & design style (space and equipment) & $x$ & $x$ & & $\mathrm{x}$ & $x$ & & & & $x$ & $x$ & & & $x$ & & & & & & & $x$ & & \\
\hline & & sustainability & & & & & & & & & & & & & & & & & & $x$ & $x$ & & $x$ & \\
\hline & & flexibility and adaptability & & $x$ & & $x$ & $x$ & & & & & & & & $x$ & & & $x$ & & $x$ & $x$ & $x$ & $x$ & \\
\hline \multirow{9}{*}{. } & t. & ventilation - natural, artificial & $\mathrm{x}$ & $x$ & & & $\mathrm{x}$ & & $\mathrm{x}$ & $x$ & $x$ & & & & $\mathrm{x}$ & $x$ & & $x$ & & $\mathrm{x}$ & & & $x$ & \\
\hline & है & noise & & $x$ & $x$ & & & & $x$ & $x$ & & & $x$ & & $x$ & $\underline{x}$ & & $x$ & $x$ & $\mathrm{x}$ & & & & \\
\hline & '̀) & comfort (thermal, acoustic) & $x$ & $x$ & & & & & & $\mathrm{x}$ & & & & & & $x$ & & & & $x$ & & & & \\
\hline &.$\stackrel{\rho}{=}$ & indoor air & & $\mathrm{x}$ & $x$ & & & & & $x$ & & & & & & $\mathrm{x}$ & & & & & & & & \\
\hline & & condition of lighting/daylight & & $x$ & & & $x$ & & $x$ & $x$ & $x$ & & $x$ & & $\mathrm{x}$ & $x \mid x$ & & $x$ & & $x$ & & & & \\
\hline & 葷 & size and location of windows & & & & & & & $x$ & & & $x$ & & $x$ & & & & & & $x$ & & & & \\
\hline & & window sill level & & & & & & & & & & & & & & & & $x$ & & & & & & \\
\hline & $\bar{\Phi}$ & privacy & & & & & $\mathrm{x}$ & & & & & & & & & $x$ & & $x$ & & $x$ & & $x$ & & \\
\hline & ठै। & view & $\mathrm{x}$ & & & $\mathrm{x}$ & & & & & $x$ & $\mathrm{x}$ & & & & $x \mid x$ & 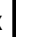 & & & $x$ & & & & \\
\hline
\end{tabular}

1 The numbers in the headers of the tables are linked to the number of references in the studied research

\subsection{Apartment unit quality assessment criteria}

Most of the studied research contained apartment unit quality assessment criteria that related to the apartments' internal organization, design, and atmosphere. To gain a better overview of the criteria, they were divided into four subgroups. The first subgroup contained criteria on general apartment unit characteristics, such as apartment area, layout, and the condition of the building elements. The second included criteria regarding individual apartment areas. These criteria evaluated the interior layout, number and existence of different rooms, net surface, and orientation to the sun. The third subgroup contained criteria concerning the apartment design, building construction, and details. Some examples include environmentally friendly designs and materials, flexibility and adaptability, and the integration of sustainable solutions. The last group of criteria included those relating to an apartment's atmosphere and comfort. They were further subdivided into three groups, which were indoor comfort, light provision, and a group that contained other ambiance characteristics such as the apartment's privacy and view. A detailed breakdown of the criteria, which covers the presence of criteria regarding apartment unit quality within specific studies, can be found in Table 1. 


\subsection{Apartment building quality assessment criteria}

The apartment building quality assessment criteria were related to an apartment building's interior and structure, as well as its immediate environment (its parcel). They were divided into five subgroups: general apartment building characteristics, structural features, common building areas, building lot, and a subgroup of other criteria important to the apartment building's assessment. General apartment building characteristics that were assessed in previous studies were as follows: building age, size and type, layout, orientation, and overall condition of the building exterior. The second subgroup of criteria concerning structure covered criteria such as structural spans and construction technology. The third subgroup was apartment building common area and included, in most of the studies evaluated, horizontal and vertical communication zones inside buildings such as entrances, elevators, staircases, and corridors. The fourth building criteria subgroup contained those related to the building's immediate surroundings, such as the existence of a parking lot or underground parking, parcel landscaping and equipment, the quality of the garbage disposal solutions, and storage areas and similar. The last subgroup contained criteria for the evaluation of building utilities, fire escapes, and fire protection, as well as accessibility for disabled people. The presence of specific criteria in different studies that focused on apartment building quality is shown in Table 2 . The table also shows the detailed division of the criteria in the subgroups, as well as the criteria within each subgroup.

Table 2 Apartment building quality assessment criteria ${ }^{2}$

\begin{tabular}{|c|c|c|c|c|c|c|c|c|c|c|c|c|c|c|c|c|c|c|c|c|c|c|c|c|}
\hline \multicolumn{2}{|r|}{ APARTMENT BUILDING quality criteria } & 19 & 16 & \begin{tabular}{|l|l}
8 & \\
\end{tabular} & \begin{tabular}{l|l|l}
20 & 34 \\
\end{tabular} & 422 & 17 & 9 & \begin{tabular}{l|l|l}
30 & 24 \\
\end{tabular} & 429 & 25 & 23 & 21 & 32 & 15 & \begin{tabular}{l|l}
28 & \\
\end{tabular} & 26 & 31 & \begin{tabular}{l|l}
18 & 33 \\
\end{tabular} & \begin{tabular}{|l|l|}
35 \\
\end{tabular} & 36 & 37 & & 41 \\
\hline \multirow{5}{*}{$\begin{array}{l}\overline{\frac{\pi}{0}} \\
\stackrel{\bar{d}}{\bar{d}} \\
. \subseteq\end{array}$} & building age & & & & & & & & & & $\mathrm{x}$ & $x$ & & & & & & & & & & & $\mathrm{x}$ & \\
\hline & building size and type & & & & $x$ & & & & & & $x$ & & $x$ & & & & $x$ & & & $x$ & & & $x$ & \\
\hline & building layout & & & & & & & & & & & & & $\mathrm{x}$ & & & & & & & & & $x$ & \\
\hline & building orientation & & $\mathrm{x}$ & & & & & & & & & & & & & & & $\mathrm{x}$ & & & & & $x$ & $x$ \\
\hline & condition of structure exterior & & & & & & & & & & $\mathrm{x}$ & & & & $\mathrm{x}$ & $x$ & & $\mathrm{x}$ & & & & & & \\
\hline \multirow{3}{*}{ 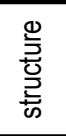 } & structural span & & & & & & & & & & & & & $\mathrm{x}$ & & & & & & & & & $\mathrm{x}$ & $x$ \\
\hline & storey height & & & & & & & & & & & & & & $\mathrm{x}$ & $\bar{x}$ & & & & $x$ & & & $\mathrm{x}$ & \\
\hline & construction technology & & & $x$ & $\bar{x}$ & & & & & & & & & & & & $x$ & & & & $x$ & & $x$ & $\bar{x}$ \\
\hline \multirow{2}{*}{ 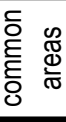 } & building entrance & & & & & & $x$ & $\mathrm{x}$ & $\bar{x}$ & & & & & $x$ & $x$ & & & $\mathrm{x}$ & & $x$ & & & & \\
\hline & $\begin{array}{l}\text { stairs/elevator/corridor (placement, } \\
\text { existence) }\end{array}$ & & & & $x$ & & $x$ & $x$ & & $x$ & $x$ & & & $x$ & $x$ & $x$ & & $x$ & & $x$ & & & $x$ & \\
\hline \multirow{3}{*}{ 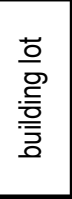 } & parking lot/underground parking & & & & $\bar{x}$ & & $x$ & $x$ & & & $x$ & $x$ & & $x$ & & $\bar{x}$ & & & & $x$ & $\mathrm{x}$ & $x$ & $x$ & \\
\hline & $\begin{array}{l}\text { parcel condition (landscaping, drives, } \\
\text { walks, tidiness) }\end{array}$ & & $x$ & & & & $x$ & & & & $x$ & & $x$ & $x$ & & $x$ & & $x$ & & $\mathrm{x}$ & $x$ & $x$ & & \\
\hline & $\begin{array}{l}\text { presence and quality of common areas ( } \\
\text { storage, trash, playground) }\end{array}$ & & $x$ & & $x$ & & & & & & $x$ & & & $\mathrm{x}$ & & & & $x$ & & $x$ & & $x$ & & \\
\hline \multirow{3}{*}{$\stackrel{\grave{\Phi}}{\mp}$} & $\begin{array}{l}\text { utilities (sewage, public water supply, } \\
\text { streets and walks, garbage disposal, } \\
\text { electricity, heating) }\end{array}$ & $x \mid$ & $x$ & $x$ & & & & $x$ & & $x$ & $x$ & $x$ & & $x$ & & & $x$ & $x$ & & $x$ & & & $x$ & \\
\hline & fire escape and protection & & & & & & & & & & & & & $\mathrm{x}$ & & & & $\mathrm{x}$ & & & & & & \\
\hline & accessibility for disabled & $x$ & & & & & & & & & & & & $\mathrm{x}$ & & $x$ & & $\mathrm{x}$ & & $\mathrm{x}$ & & & & \\
\hline
\end{tabular}

2 The numbers in the headers of the tables are linked to the number of references in the studied research

\subsection{Neighborhood quality assessment criteria}

Neighborhood quality assessment criteria are criteria that were used for the quality assessment of a building's closer or wider surroundings. These criteria were grouped around four subgroups: general neighborhood characteristics, traffic, hazards, and the existence of and distance from different services and facilities. The first subgroup of the criteria contained general characteristics of the neighborhood, such as the condition of adjacent structures, and building and population density. The traffic criteria subgroup included criteria concerning the condition of surrounding streets, accessibility to and proximity of different kinds of public transportation, traffic nuisances, etc. Several studies have assessed the dangers that may be present near a residential building, such

Brkanić, I 
as flooding or industrial pollution. Those dangers were collected into the third subgroup, named hazards. The largest subset of criteria inside the neighborhood quality assessment criteria was the presence of services and facilities. This subgroup contained criteria for assessing the presence of certain facilities in the residential neighborhood, such as shops, restaurants, schools, medical centers, recreational facilities, etc. Table 3 shows the subgroups of the criteria for neighborhood quality assessment and the presence of a particular criterion in the analyzed studies.

Table 3 Neighborhood quality assessment criteria ${ }^{3}$

\begin{tabular}{|c|c|c|c|c|c|c|c|c|c|c|c|c|c|c|c|c|c|c|c|c|}
\hline \multicolumn{2}{|r|}{ NEIGHBOURHOOD quality criteria } & \begin{tabular}{|l|l|}
19 & 16 \\
\end{tabular} & \begin{tabular}{|l|l|}
8 & 2 \\
\end{tabular} & \begin{tabular}{|l|l|}
0 & 34 \\
\end{tabular} & \begin{tabular}{l|l|l}
22 & 17 \\
\end{tabular} & 9 & \begin{tabular}{|l|l|}
30 & 24 \\
\end{tabular} & \begin{tabular}{l|l}
4 & 29 \\
\end{tabular} & 25 & 23 & 21 & 32 & 15 & $28 / 2$ & 631 & \begin{tabular}{l|l|l}
18 & 33 \\
\end{tabular} & 35 & 36 & 37 & \begin{tabular}{l|l|}
40 & 41 \\
\end{tabular} \\
\hline \multirow{3}{*}{ 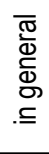 } & condition of adjacent structures and parcels & & & & & $x$ & & & & & & $x$ & & & & & $\mathrm{x}$ & & & \\
\hline & building and population density & & & & & $\mathrm{x}$ & & & & & & & $\mathrm{x}$ & & & & $\mathrm{x}$ & & & \\
\hline & district name - location & & & $x$ & & & $x$ & $x$ & $x$ & $x$ & & & & & & & & & & \\
\hline \multirow{5}{*}{ 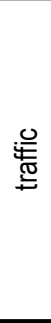 } & $\begin{array}{l}\text { condition of sidewalk, street, curbs, and } \\
\text { alleyway }\end{array}$ & & & & & $\mathrm{x}$ & & & & & & & & & $\mathrm{x}$ & & $\mathrm{x}$ & $\mathrm{x}$ & & \\
\hline & $\begin{array}{l}\text { traffic - access (proximity of major traffic } \\
\text { streets and railroads) }\end{array}$ & & & $\mathrm{x}$ & & & & & & $\mathrm{x}$ & & $\mathrm{x}$ & & $\mathrm{x}$ & $\mathrm{x}$ & & $\mathrm{x}$ & $\mathrm{x}$ & $x$ & \\
\hline & traffic - nuisance (streets, railroads, airport) & $x$ & & & & $\mathrm{x}$ & & & & & & & & & $x$ & & $\mathrm{x}$ & $x$ & $x$ & \\
\hline & parking & & & & & $\mathrm{x}$ & & & & & & & & & & & $\mathrm{x}$ & & & \\
\hline & pedestrian network & & & $\mathrm{x}$ & & & & & & & & & & & & & $\mathrm{x}$ & & $\mathrm{x}$ & \\
\hline 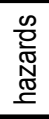 & $\begin{array}{l}\text { hazards and nuisances from natural causes } \\
\text { (flooding, swamps, topography) and } \\
\text { industry }\end{array}$ & $\mathrm{x}$ & & & & & & & & & & & & & $\mathrm{x}$ & & $\mathrm{x}$ & & & \\
\hline \multirow{7}{*}{ 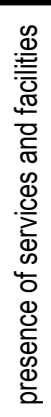 } & $\begin{array}{l}\text { commercial facilities (shops, market, } \\
\text { restaurants) }\end{array}$ & $\mathrm{x}$ & & $\mathrm{x}$ & & & $\mathrm{x}$ & $x$ & & $\mathrm{x}$ & & $\mathrm{x}$ & & $\mathrm{x}$ & $\mathrm{x}$ & $\mathrm{x}$ & $\mathrm{x}$ & $x$ & $x$ & \\
\hline & cultural and educational facilities & $x$ & & $\mathrm{x}$ & & $\mathrm{x}$ & & & & $x$ & $x$ & $x$ & & $x$ & $x$ & $x$ & $x$ & $x$ & $x$ & \\
\hline & post office, bank & & & & & & & & & & & & & & $\mathrm{x}$ & & $x$ & & & \\
\hline & $\begin{array}{l}\text { distance to the medical center, healthcare } \\
\text { facility }\end{array}$ & $\mathrm{x}$ & & & & & & & & & & $\mathrm{x}$ & & $\mathrm{x}$ & $\mathrm{x}$ & $\mathrm{x}$ & $\mathrm{x}$ & & & \\
\hline & $\begin{array}{l}\text { distance from main street/inner street/city } \\
\text { centre }\end{array}$ & & & & & & & & & & $\mathrm{x}$ & $\mathrm{x}$ & & & $\mathrm{x}$ & $\mathrm{x}$ & $\mathrm{x}$ & & $x$ & \\
\hline & recreation facilities, playgrounds & $\mathrm{x}$ & & & & $\mathrm{x}$ & & & & & & $\mathrm{x}$ & & & $\mathrm{x}$ & & $x$ & $x$ & $x$ & \\
\hline & parks, lakes, and forests & $\mathrm{x}$ & & $\mathrm{x}$ & & $\mathrm{x}$ & & & & & & $\mathrm{x}$ & & $\mathrm{x}$ & $\mathrm{x}$ & & & $x$ & $x$ & \\
\hline
\end{tabular}

${ }^{3}$ The numbers in the headers of the tables are linked to the number of references in the studied research

\subsection{Social and economic criteria for housing quality assessment}

The last set of criteria that were used in previous studies on housing quality encompassed the social and economic aspects of housing. This group of criteria was also subdivided into smaller subgroups: finance, family size, social relations, and other. The subgroup regarding finances had two smaller subgroups that dealt with evaluations of family expenses and living standards. Because of room numbers and the occupancy factor, family size is an important criterion, and as such, it was separated into a second subgroup. The social relations subgroup gathered the third set of criteria, which evaluated communication, friendliness, social solidarity, and neighbors' characteristics. The last subgroup of criteria covered crime prevention, privacy protection, and overall housing satisfaction. The presence of social and economic criteria for housing quality within a specific study and classification of criteria is shown in Table 4. 
Table 4 Social and economic criteria for housing quality assessment ${ }^{4}$

\begin{tabular}{|c|c|c|c|c|c|c|c|c|c|c|c|c|c|c|c|c|c|c|c|c|c|}
\hline \multicolumn{2}{|r|}{ SOCIAL and ECONOMIC criteria } & 19 & \begin{tabular}{l|l}
16 & 8 \\
\end{tabular} & 20 & 34 & 22 & 17 & \begin{tabular}{l|l}
9 & 3 \\
\end{tabular} & \begin{tabular}{l|l|l|}
30 & 24 \\
\end{tabular} & 29 & $25 \mid 2$ & 23 & 213 & \begin{tabular}{l|l}
32 & 1 \\
\end{tabular} & \begin{tabular}{|l|l|}
5 & 28 \\
\end{tabular} & 26 & $31 \mid 1$ & \begin{tabular}{lll|}
8 & 33 \\
\end{tabular} & 35 & & 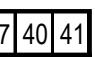 \\
\hline \multirow{5}{*}{$\stackrel{5}{\rightleftarrows}$} & general housekeeping (maintenance) & & & & $x$ & & & $x$ & & & $\mathrm{x}$ & $\mathrm{x}$ & & $x$ & $x$ & & $x$ & & & $\mathrm{x}$ & \\
\hline & energy and cost conservation & & & & $x$ & & & & & & & & r & $x$ & & & & & & & \\
\hline & apartment sale price & & & & $\mathrm{x}$ & & & & $x$ & & & & $x$ & & & & & & & & \\
\hline & family income & & & & $\mathrm{x}$ & & & & $x$ & & & & & & & & & $\mathrm{x}$ & & & \\
\hline & standard of living & & & & & & & & $\mathrm{x}$ & & $x$ & & & & $\mathrm{x}$ & & & & & & \\
\hline \multirow{2}{*}{ 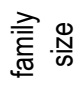 } & family size & & & & $\mathrm{x}$ & & & & & & & & & & & & & $\mathrm{x}$ & & & $\mathrm{x}$ \\
\hline & room occupancy factor & & $x$ & & & & & & & & & & & & & & & $x$ & & & \\
\hline \multirow{2}{*}{ 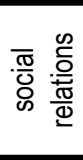 } & $\begin{array}{l}\text { communication with and attitude and } \\
\text { characteristics of neighbors }\end{array}$ & & & & & & & $x$ & & & & $x$ & & & $x$ & $x$ & & & & & \\
\hline & $\begin{array}{l}\text { Social solidarity and community } \\
\text { friendliness }\end{array}$ & & & & & & & & $\mathrm{x}$ & & $x$ & $x$ & r & $x$ & $x$ & & & $x$ & & & \\
\hline \multirow{2}{*}{ 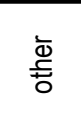 } & $\begin{array}{l}\text { crime prevention and privacy protection - } \\
\text { security }\end{array}$ & & & & $x$ & & & $x$ & & & & $x$ & r & $x$ & $x$ & & $x$ & $\mathrm{x}$ & $x$ & & \\
\hline & overall satisfaction & $x$ & & & $\mathrm{x}$ & $\mathrm{x}$ & & & & & & & & & $x$ & & & & & $x$ & \\
\hline
\end{tabular}

4 The numbers in the headers of the tables are linked to the number of references in the studied research

\section{DISCUSSION}

Based on a study of the existing research, this paper defined four groups of criteria used to assess housing quality. The groups cover the apartment unit, apartment building, apartment neighborhood, and social and economic housing conditions. These groups were further divided into 17 subgroups containing 66 individual criteria in total.

Between the four subgroups of apartment unit quality, the most commonly identified one concerned an apartment's ambiance. The most common individual criterion for apartment unit quality was one in the subgroup named rooms that evaluated the quality of rooms' interiors, followed by criteria on room sizes, location, number, and orientation. The least used subgroup of apartment building quality criteria was the one dealing with general apartment features, such as apartment area, unit layout, etc. In the apartment unit quality criteria group, two of the least used individual criteria were the high-tech technology criterion from the construction subgroup and the window sill level criterion from the ambience subgroup.

The research showed that the most important criteria for apartment building quality were those in the building lot subgroup, followed by the almost equally represented criteria contained in the following subgroups: general, common areas, and other. The least used criteria were those grouped in the structure subgroup. The most common individual criterion in the apartment building quality group was the one regarding the quality of apartment building installations and utilities in the subgroup named other.

The subgroup of criteria that measured the presence of services and facilities was the most common in the neighborhood quality criteria group. The most common individual criterion within this subgroup was that on the presence of cultural and educational facilities. It is interesting that the least common individual criterion was the presence of and distance to the post office or bank, which can be explained as the result of new information technologies. The least used criteria subgroup for neighborhood quality assessment was that regarding safety(specifically, the criterion named hazards).

Within the criteria that dealt with the social and economic characteristic of housing, only two individual criteria can be singled out. They are the criterion for maintenance expenses in the finance and security subgroup (which covered crime prevention) and the privacy protection criterion in the subgroup other. In general, most individual criteria within the social and economic criteria group were among the least used criteria in previous research.

The criteria presented in this paper can be divided according to the spaces on different scales (apartment unit, apartment building, and neighborhood) and according to the method of assessment. The latter include quantitative or measurable criteria (size, position and orientation of the apartment, structural span, the existence of different facilities, etc.) and qualitative criteria that relate to individual assessments (comfort, privacy, view, and overall satisfaction). 


\section{CONCLUSION}

The research presented in this paper provided a comprehensive overview of the criteria used for the evaluation of housing quality in existing studies. The defined criteria were grouped into four categories: apartment unit quality criteria, apartment building quality criteria, apartment neighborhood quality criteria, and social and economic criteria. The results showed that, among these four groups, the most common criteria were those regarding the apartment unit, while the least represented were those related to the housing's social and economic conditions. The subgroup of criteria that measured the quality of the ambience in apartment units contained the criteria that were the most frequently used in previous research. The second most important subgroup was the one that measured the presence of services and facilities within the neighborhood quality criteria group. The most common individual criterion was the one regarding the interiors of living rooms, kitchens, bedrooms, and bathrooms in the rooms subgroup in the apartment unit quality criteria group.

Looking at the studied research, one can notice an increase in the numbers of individual criteria and criteria groups over time. Also, their divisions are becoming more complex and require the introduction of new subgroups. This trend suggests that the number of criteria related to adaptability; flexibility; high-tech solutions; and the application of sustainable materials, construction, and design in general will increase and lead to even more complex relations between the criteria.

The defined criteria can be used in future research and can serve as a basis for the proposal of a set of highly valuable criteria for examining attitudes toward housing quality. Such research could provide a general housing quality assessment.

Although the presented criteria groups covered the vast majority of criteria used to assess housing quality, when assessing housing quality related to a specific user or apartment type, attention should be paid to the characteristics and interests of that user and the specific apartment features.

\section{References}

[1] Nurdini, A.; Belgawan Harun, I. 2012: Spatial bounded-choice behavior within the consumer of rental housing in Bandung, Indonesia, Journal of Asian Behavioral Studies, 2 (4), pp. 58-68, https:/doi.org/10.1016/i.sbspro.2012.03.021

[2] Kurian, S. M.; Thampuran, A. 2001: Assessment of housing quality, Institute of Town Planners, India Journal, 8 (2), pp. 74-85

[3] Lu, M. 1999: Determinants of residential satisfaction: Ordered logit vs. regression models, Growth and Change, 30, pp. 264-287, https://doi.org/10.1111/0017-4815.00113

[4] Ministarstvo zaštite okoliša i prostornog uređenja, Zavod za prostorno uređenje, 2013: Izvješće o stanju u prostoru Republike Hrvatske, Zagreb [In Croatian]

[5] Meng, G.;Hall, G. B. 2006: Assessing housing quality in metropolitan Lima, Peru, Journal of Housing and Built Environment, 21, pp. 413-439, https://doi.org/10.1007/S10901-006-9058-1

[6] Kincl, B.; Delić, A. 2002: Razvoj arhitektonskog okoliša (arhitektonske cjeline), XXX IAHS, World Congress on Housing, Housing Construction - An Interdisciplinary Task, [ur. Ural, O.; Abrantes, V.; Tadeu, A.], Coimbra: Wide Dreams Projectos Multimedia, Lda. pp. 215-222, Coimbra, Portugal

[7] Elsinga, M.;Hoekstra, J. 2005: Homeownership and housing satisfaction, Journal of Housing and the Built Environment, 20, pp. 401-424, https://doi.org/10.1007/S10901-005-9023-4

[8] Streimikiene, D. 2015: Quality of life and housing, International Journal of Information and Education Technology, 5 (2), pp. 140-145, https:/doi.org/10.7763/IJIET.2015.V5.491

[9] Mridha, M. 2015: Living in an apartment, Journal of Environmental Psychology, 43, pp. 42-54, https://doi.org/10.1016/i.jenvp.2015.05.002

[10] Amole, D. 2009: Residential satisfaction in students' housing, Journal of Environmental Psychology, 29, pp. 76-85, https://doi.org/10.1016/i.jenvp.2008.05.006

[11] Poljanec, G. 2001: Stalno i promjenjivo u stanovanju, Prostor, 9 (1), pp. $67-77$ [in Croatian]

[12] Solow, A. A. 1946: Measuring the quality of urban housing environment: A new appraisal technique, The Journal of Land \& Public Utility Economics, 22 (3), pp. 282-293, https://doi.org/10.2307/3159048

[13] Twichell, A.A. 1948: An appraisal method for measuring the quality of housing, American Sociological Review, 13 (3), pp. 278-287 
[14] Kain, J. F.; Quigley J. M. 1970: Measuring the value of housing quality, Journal of the American Statistical Association, 65 (330), pp. 532-548, https://doi.org/10.1080/01621459.1970.10481102

[15] Acre, F.; Wyckmansa, A. 2014: Spatial quality determinants for residential building renovation: A methodological approach to the development of spatial quality assessment, International Journal of Sustainable Building Technology and Urban Development, 5 (3), pp. 183-204, https://doi.org/10.1080/2093761X.2014.923793

[16] Bezak, S.; Horvat, B.; Beler, M. 2005: Vrednovanje korisnog prostora u višestambenim zgradama, Građevinar, 57 (3), pp. 157-162 [in Croatian]

[17] Choi, J.; Cho, T.; 2014: Comparing perception concerning the importance of apartment complex components between consumers and housing providers, Journal of Asian Architecture and Building Engineering, 13 (1), pp. 109-116, https://doi.org/10.3130/jaabe.13.109

[18] Kang, N. N.; Lee, T. K.; Kim, J. T.; Kim, C. G. 2014: Residents' and experts' perspectives for evaluation of importance of health performance indicators in social housings, indoor and built environment, 23 (1), pp. 150-160, https://doi.org/10.1177/1420326X14523156

[19] Homadovski, A.; Rogić, I. 1999: Arhitektonsko vrednovanje višestambenih zgrada i stanova za zbrinjavanje stradalnika Domovinskog rata: Sociologijsko vrednovanje stanova stradalnika Domovinskog rata, Prostor, 7 (2), pp. 225-240 [in Croatian]

[20] James, R.N. III 2007: Multifamily housing characteristics and tenant satisfaction, Journal of Performance of Constructed Facilities, 21, November/December, pp. 472-480, https://doi.org/10.1061/(ASCE)0887-3828(2007)21:6(472)

[21] Opoku, R.A.; Abdul-Muhmin, A.G. 2010: Housing preferences and attribute importance among low-income consumers in Saudi Arabia, Habitat International, 34, pp. 219-227, https://doi.org/10.1016/j.habitatint.2009.09.006

[22] Sima, L. 2015: Study on small apartment design in China: Evaluation on the impressions of and preferences for the floor plans, Journal of Asian Architecture and Building Engineering, 14 (2), pp. 307-314, https://doi.org/10.3130/jaabe.14.307

[23] Grum, B.; Kobal Grum, D. 2014: Satisfaction with current residence status in comparison with expectations of real estate buyers in Slovenia and Serbia, Procedia - Social and Behavioral Sciences, 109, pp. 263-275, https://doi.org/10.1016/j.sbspro.2013.12.456

[24] Haddad, M.; Judeh, M.; Haddad, S. 2011: Factors affecting buying behavior of an apartment: An empirical investigation in Amman, Jordan, Research Journal of Applied Sciences, Engineering and Technology, 3 (3), pp. 234-239

[25] Nahtigal, D; Grum, B. 2015: Segmentation and the Value frame of buyers of residential apartments, Geodetski vestnik, 59 (1), pp. 71-101, https://doi.org/10.15292/geodetski-vestnik.2015.01.071-101

[26] Gann, D.M.; Salter, A.J.; Whyte, J.K. 2003: Design quality indicator as a tool for thinking, Building Research \& Information, 31 (5), pp. 318-333, https://doi.org/10.1080/0961321032000107564

[27] Kang, N.N.; Kim, J.T.; Lee, T.K. 2014: A study on the healthy housing quality of multi-family attached house according to dwelling unit age, Energy Procedia, 62, pp. 595-602, https://doi.org/10.1016/j.egypro.2014.12.422

[28] Cho, S.H.; Kang, N.N. 2011: A study on the evaluation of healthy housing quality of apartments, 5th International Symposium on Sustainable Healthy Buildings, Seoul, Korea, February 102011

[29] Bennett, J. et al. 2016: Towards an agreed quality standard for rental housing: Field testing of a New Zealand housing WOF tool, Australian and New Zealand Journal of Public Health, pp. 1-7, https://doi.org/10.1111/1753-6405.12519

[30] Kim, S.S.; Yang, I.H.; Yeo, M.S.; Kim, K.W. 2005: Development of a housing performance evaluation model for multifamily residential building in Korea, Building and Environment, 40, pp. 1103-1116, https://doi.org/10.1016/j.buildenv.2004.09.014

[31] Tibesigwa, B.M.; Hao, L.; Karumuna, B.V. 2017: The concept of spatial quality and its challenges on exercised affordable housing design typology in Dar es Salaam - Tanzania, Habitat International, 59, pp. 44-59, https://doi.org/10.1016/j.habitatint.2016.11.010

[32] Lea, L.H.; Ta, A.D.; Dang, H.Q. 2016: Building up a system of indicators to measure social housing quality in Vietnam, Procedia Engineering, 142, pp. 115-122, https://doi.org/10.1016/j.proeng.2016.02.021

[33] Huang, Z.; Du, X. 2015: Assessment and determinants of residential satisfaction with public housing in Hangzhou, China, Habitat International, 47, pp. 218-230, https://doi.org/10.1016/j.habitatint.2015.01.025

[34] Shin, E.K.; Hong, S.; Kim, S.2016: Changes in public perception of apartments: Television and newspaper advertisements, 1960-2010, Journal of Asian Architecture and Building Engineering, 15 (1), pp. 65-72, https://doi.org/10.3130/jaabe.15.65

[35] Housing Quality Indicators HQI - https://www.gov.uk/guidance/housing-quality-indicators\#hqi-calculator, Accessed February 9 2017)

[36] Building for life - http://webarchive.nationalarchives.gov.uk/20110118095356/http://www.buildingforlife.org/ criteria, last accessed February 92017.

[37] Housing Assessment System - SEL http://www.wbs.admin.ch/fr/application/catalogue-de-criteres?open=k23, last accessed 9 February 2017.

Brkanić, I 
Housing quality assessment criteria

[38] Poljanec, G. 2001: Poželjna svojstva stana, Ph.D. thesis, University of Zagreb [in Croatian]

[39] Čaldarović, O.; Richter, M. 1978: Sociološko istraživanje načina intenziteta korištenja stambenih prostora u Zagrebu, Zagreb: Građevinski institut. [in Croatian]

[40] Vezilić Strmo, N. 2012: Model procjene održivosti postojećih stambenih zgrada - na primjeru višestambene izgradnje u Zagrebu od 1945. do 1975. godine, Ph.D. thesis, University of Zagreb [in Croatian]

[41] Korlaet, L. 2015: Prostorni razvoj stana u Zagrebu 1975-2005. u okvirima programa društveno poticajne stanogradnje, Ph.D. thesis, University of Zagreb [in Croatian] 